ВИЗНАЧЕННЯ РОЛІ І МІСЦЯ ВИРОБНИЧИХ ЗАВДАНЬ У ПРОЦЕСІ ФОРМУВАННЯ ПРОФЕСІЙНОӤ КОМПЕТЕНТНОСТІ МАЙБУТНІХ МАЙСТРІВ ВИРОБНИЧОГО НАВЧАННЯ ТРАНСПОРТНОГО ПРОФІЛЮ

\title{
DETERMINATION OF THE ROLE AND PLACE OF PRODUCTION TASKS IN THE PROCESS OF FORMATION OF PROFESSIONAL COMPETENCE OF FUTURE MASTERS OF PRODUCTION TRAINING
}

\begin{abstract}
у статmі визначаються роль та місце виробничих завдань у процесі формування профресійної компетентності майбутніх майстрів виробничого навчання транспортного профрілю. У контексті цієї проблеми на основі аналізу психолого-педагогічної літератури узагальнені підходи до проблематики обґрунтування структурних компонентів педагога профресійного навчання.

Встановлено, що професійна компетентність майбутніх майстрів виробничого навчання транспортного профрілю включає особистісну об'єднувальну характеристику срахівия, яка відображає прагнення та вміння здійснювати на високому рівні виробничу діяльність, виконувати просресійні обов'язки, компетентно вирішувати поставлені проблеми за допомогою набутих знань, навичок і вмінь під час навчання, есрективно мобілізуватиме власні здібності та досвід залежно від конкретної виробничої ситуації, ілюструватиме еластичність і креативність творчого мислення під час розв'язування виробничих завдань.

Під час дослідження запропонована структура формування професійної компетентності майбутніх майстрів виробничого навчання транспортного профрілю, яка включає когнітивний, мотиваційний, діяльнісний та особистісний компоненти.

Обгрунтовано фрормування профресійної компетентності майбутніх майстрів виробничого навчання транспортного профрілю виробничими завданнями в навчально-виробничій діяльності. Відповідно до поставленої мети дослідження авторами наведені виробничі завдання, які фрормують професійну компетентність майбутніх майстрів виробничого навчання транспортного профрілю. Дослідження засвідчують, що респонденти не приділяють необхідної уваги впровадженню для активізації освітньоі діяльності, підвищення мотивації навчання нетрадиційних лекцій, що побудовані на розв'язуванні виробничих завдань.

Доведено, що впровадження одного з методів інноваційних технологій розв'язування виробничих завдань у процес фрормування профресійної компетентності майбутніх майстрів виробничого навчання транспортного профрілю сприятиме фрормуванню вмінь i навичок інформаційної і комунікативної взаємодії, збільшенню обсягу навчального матеріалу для творчого засвоєння й подальшого використання.
\end{abstract}

Ключові слова: компетентність, майстер виробничого навчання транспортного профрілю, інноваційні технології, виробничі завдання.

The article defines the role and place of production tasks in the process of formation of professional competence of future masters of industrial training of transport profile. In the context of this problem on the basis of the analysis of psychological and pedagogical literature the approaches to a problem of a substantiation of structural components of the teacher of professional training are generalized. It is established that the professional competence of future masters of industrial training of transport profile includes a personal unifying characteristic of the specialist, which reflects the desire and ability to carry out high-level production activities, perform professional duties, competently solve problems using the acquired knowledge, skills and abilities. training time will effectively mobilize their abilities and experience depending on the specific production situation, illustrating the elasticity and creativity of creative thinking in solving production problems

During the research the structure of formation of professional competence of future masters of industrial training of transport profile which includes cognitive, motivational, activity and personal components is offered.

The formation of professional competence of future masters of industrial training of transport profile by production tasks in educational production activity is substantiated. In accordance with the purpose of the study, the authors present production tasks that form the professional competence of future masters of industrial training of transport profile. Research shows that respondents do not pay the necessary attention to implementation to intensify educational activities, increase motivation to teach nontraditional lectures, which are based on solving production problems.

It is proved that the introduction of one of the methods of innovative technologies to solve production problems in the process of forming professional competence of future masters of industrial training of transport profile will promote the formation of skills of information and communication, increase the amount of educational material for creative learning and further use. Key words: competence, master of industrial training of transport profile, innovative technologies, production tasks.
Постановка проблеми в загальному вигляді. Профресійна діяльність майбутнього майстра виробничого навчання транспортного профрілю успішна тоді, коли ще під час навчання у вищому та фраховому передвищому навчальних закладах він набуває досвіду практичної діяльності. Основу успішної професійної діяльності майбутнього фрахівця становить профресійна компетентність, яка передбачає опанування знань, умінь і навичок у транспортній сорері, уміння застосовувати набуті знання в розв'язанні виробничих завдань, прагнення до аналізу проблемних ситуацій і пошуку шляхів виходу з них. Сорормовані професійні компетентності використовуються як у практичній 
діяльності за фрахом, так і у виробничій діяльності фрахівців транспортного профрілю. Отже, професійна компетентність майбутнього майстра виробничого навчання транспортного профрілю виявляється в готовності здійснювати певну виробничу діяльність у конкретних ситуаціях.

Аналіз останніх досліджень і публікацій. Розвиток компетентнісного підходу як науковий пошук досліджено в роботах Н. Бібік, Л. Ващенко, М. Голованя, В. Ковальчука, Г. Ігнатенко, О. Локшини, П. Лузана, Н. Ничкало, О. Овчарук, Л. Паращенко, О. Пометун, В. Радкевич, І. Родигіної, Г. Селевка й інших. Проаналізовано теоретичні основи використання компетентнісного підходу у працях таких науковців, як: І. Зимня, Н. Кузьміна, Л. Курнешова, А. Маркова, Н. Щуркова й інші. Розвитком та фрормуванням професійної компетентності під час вивчення фрізики цікавилися П. Атаманчук, В. Вовкотруб, В. Бургун, М. Галатюк, М. Садовий, О. Трифонова, В. Шарко й інші.

Серед закордонних науковців досліджували проблему компетентності Т. Хайланд (T. Hyland), Дж. Равен (J. Raven), В. Ротуелл (W. Rothwell), Е. Шорт (E. Short), P. Вайт (R. White) та інші.

Виділення не вирішених раніше частин загальної проблеми. Проблема фрормування професійної компетентності майбутніх майстрів виробничого навчання транспортного профрілю виробничими завданнями в зазначених та інших роботах не розглядається, що й зумовило актуальність теми статті.

Мета статті - визначення ролі та місця виробничих завдань у процесі фрормування професійної компетентності майбутніх майстрів виробничого навчання транспортного профрілю.

Виклад основного матеріалу. На сучасному етапі розвитку суспільства в умовах глобальних суспільних зрушень, які мають систематичний, швидкий, здебільшого незворотний характер, чи не головне місце посідає освіта. Освіта сьогодні $€$ тим соціальним інститутом, через який проходить кожна людина. Саме тому сучасний майстер виробничого навчання транспортного профрілю відіграє провідну роль у процесі формування особистості, громадянина держави. Так, у зв'язку із входженням України в європейський та світовий соціокультурний, освітній простір виникла нагальна потреба у зміні системи підготовки майстра виробничого навчання транспортного профрілю, у необхідності фрормування професійної компетентності.

Кожен сучасний майстер виробничого навчання транспортного профрілю упродовж професійної діяльності прагне самовдосконалюватися, розвиватися, професійно зростати, щоб бути конкурентоспроможним на сучасному ринку праці, особливо в гіперінорорматизованому суспільстві. Наполеглива праця, опанування інноваційних освітніх технологій, обмін досвідом, участь у конфреренціях, міжнародне стажування, проходження тренінгів, вебінарів та педагогічних курсів можуть стати джерелом профресійних навичок. Бути майстром виробничого навчання транспортного профрілю сьогодні - це бути професіоналом своєї справи, спеціалістом, другом і порадником, щоб мотивувати студентів до навчання, самовдосконалення та творчої діяльності.

Формування профресійної компетентності майстра виробничого навчання транспортного профрілю має важливий вплив на його прагнення вдосконалюватися. Студенти можуть водночас вирішувати завдання під час навчально-виробничої діяльності.

Оновлення навчального процесу в освітньому середовищі підштовхує майстрів виробничого навчання транспортного профрілю відшукати відповіді на поставлені запитання та спонукає їх використовувати творчі підходи, що спричиняє до професійного зростання та фрормування його індивідуальних інтересів, пов'язаних із навчанням.

Профресійний та творчий розвиток студентів сприятливо впливає на створення атмосорери навчального закладу. Це також важливо для формування професійної компетентності майстра виробничого навчання транспортного профілю в межах інноваційного середовища на основі творчої співпраці, що дозволить спільне вирішення важливих педагогічних проблем.

Водночас у навчальному процесі виникає складність профресійно-педагогічної діяльності майстра виробничого навчання транспортного профілю, пов'язана з постійним розумовим та емоційним напруженням, подоланням психологічних та педагогічних труднощів. Розвиток сучасної навчально-виховної роботи зумовлює появу нових змістовних і процесуальних характеристик педагогічної діяльності. Заданий темп упровадження інновацій в освітній процес не завжди відповідає можливостям педагога в реальних умовах роботи, оскільки для виконання поставлених завдань майстер виробничого навчання транспортного профрілю повинен володіти досить високим рівнем профресійної компетентності.

У нашому дослідженні ми розглядаємо поняття профресійної компетентність як персональну інтегративну характеристику фахівця, яка відображає сильнодіючу комбінацію вмінь, знань і практичних навичок із кваліфікованого вирішення проблем, визначає здатність студента успішно виконувати професійну діяльність, майстерно мобілізувати власні здібності та досвід залежно від ситуації, показувати гнучкість і креативність мислення [12].

Розгляд професійної компетентності майстра виробничого навчання як динамічного поняття, в основі якого покладено як професійно-теоретичну, так і профресійно-практичну підготовку, а 
також фрормування особистісних, психологічних якостей, цінностей, професійно важливих здатностей, зумовлює необхідність системного підходу.

У наукових доробках під час розгляду окремого явища зазвичай звертаються до його структури (лат. structura, англ. structure, рос. структура, нім. Struktur).

Узагальнення підходів до проблематики обґрунтування структурних компонентів профресійної компетентності педагога професійного навчання дозволяє виокремити у структурі професійної компетентності майбутнього майстра виробничого навчання такі компоненти [6, с. 194]:

- мотиваційний компонент є пусковим механізмом до здобуття професії, опанування знань і вмінь застосовувати інноваційні технології у профресійній діяльності;

- когнітивний компонент дозволяє задовольнити й розвинути потреби, інтереси, мотиви й ціннісні орієнтації майстрів виробничого навчання транспортного профрілю на основі наявної системи знань і вмінь із використання інноваційних технологій у професійній діяльності;

- діяльнісний компонент - це комплекс умінь, що дозволяють здійснювати професійну діяльність;

- особистісний компонент - це сукупність важливих для професійної педагогічної діяльності особистісних якостей.

На рисунку 1 схематично представлено структуру професійної компетентності майстра виробничого навчання транспортного профрілю. Зазначимо тісну взаємозалежність та єдність вказаних компонентів.

Реалізація компетентнісного спрямування в освітньому процесі здійснюється на всіх етапах навчання, упродовж вивчення кожного освітнього компонента, що стосується як їхнього змісту, так і технологій навчання.

У процесі дослідження проблем орормування профресійної компетентності майстрів виробничого навчання транспортного профілю варто вказати на особливість їхньої професійної діяльності.

Зважаючи на особливості професійної діяльності майстра виробничого навчання транспортного профрілю та фрормування професійної компетентності, можемо стверджувати, що підготовка такого фрахівця потребує визначення педагогічних умов, які сприятимуть результативності такого процесу. У науково-педагогічній літературі під педагогічними умовами розуміють сукупність заходів педагогічного процесу (підготовчий, основний, підсумковий), спрямованих на з'ясування поставлених завдань (мета, діагностика умов, прогнозування досягнень, проєктування і планування розвитку прочесу).

Педагогічні умови ефрективного фрормування професійної компетентності майбутніх майстрів виробничого навчання транспортного профілю засобами інноваційних технологій створюють необхідну й достатню сукупність заходів педагогічного процесу, який забезпечує досягнення студентом високого рівня сорормованості профресійної компетентності.

Аналіз досліджуваної проблеми й опрацювання наукової літератури за зазначеними напрямами дозволили нам виділити такий комплекс педагогічних умов, як:

- спрямованість в організації та реалізації аудиторної роботи на позитивно-ціннісне ставлення майбутніх майстрів виробничого навчання транспортного профрілю до розвитку професіоналізму;

- проєктування навчального процесу, яке передбачає розроблення змісту лекцій, завдань для самостійної роботи студентів, педагогічних, дидактичних і методичних завдань, що розв'язуються на практичних та виробничих заняттях, навчальних проєктів проблемного характеру;

- застосування інноваційних технологій навчання, що моделюють зміст діяльності викладача, допомагають наблизити навчальний процес до реальної профресійної діяльності;

- активізація аудиторної та самостійної роботи студента, спрямованої на розв'язування виробничих завдань в умовах інтерактивного спілкування.

Важлива складова частина змістового і діяльнісного компонентів - задачний підхід під час вивчення дисциплін в закладах вищої та фрахової передвищої освіти. Лише розуміння змістового наповнення задачного підходу й інноваційної технології його реалізації зазнає нині суттєвих змін. Як уважає Л. Буркова, «парадигма компетентнісного підходу має ґрунтуватися на задачному підході, який, у свою чергу, базується на діяльнісному

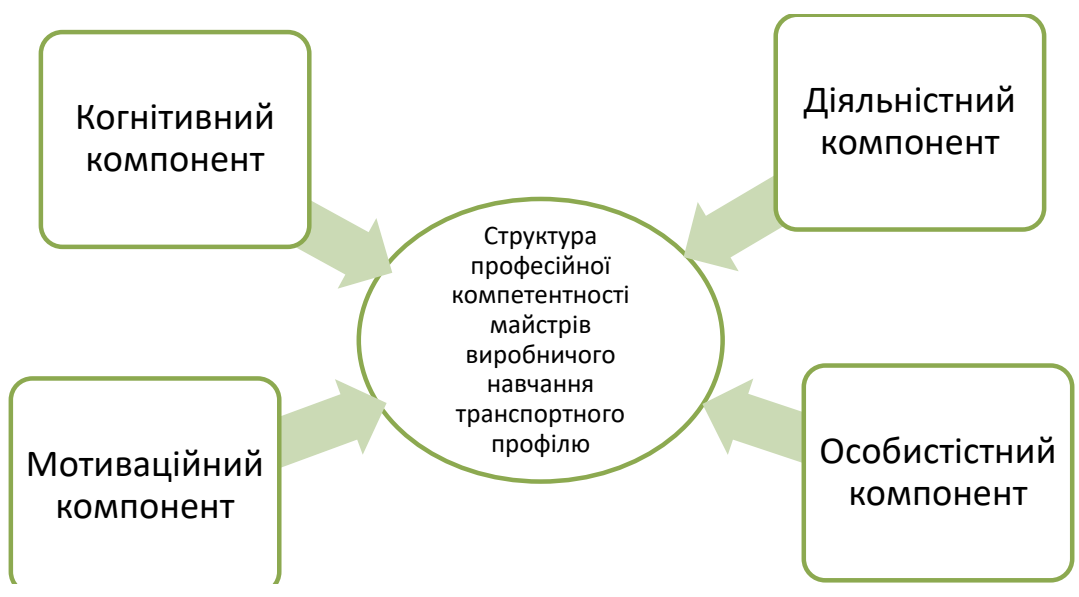

Рис. 1. Структура професійної компетентності майстра виробничого навчання транспортного профрілю 
і відповідає меті якісної підготовки фрахівців у вищій школі» [1]. Провідним положенням розв'язування завдань у навчанні $€$ твердження, що майже вся навчально-пізнавальна діяльність може бути представлена яксистемапізнавальних завдань (Г. Балл, В. Давидов, Є. Машбиць, Л. Фрідман та інші).

Методика фрормування профресійної компетентності майбутніх майстрів виробничого навчання транспортного профрілю засобами розв'язування завдань розробляється 3 метою організації навчально-пізнавальної діяльності. Виокремимо її основні етапи - постановка й розв'язування виробничих завдань. На першому етапі здійснюється обґрунтування практичної діяльності студентів, на другому - розроблення алгоритму розв'язування виробничих завдань.

Використання розв'язку виробничих завдань в освіті сприяє інтенсифікації й підвищенню ефективності процесу навчання, створює умови для самоосвіти і саморозвитку, у поєднанні 3 інтерактивними технологіями розв'язує проблему доступу до нових джерел навчальної інсрормації. Включивши виробничі завдання до процесу фрормування професійної компетентності майбутніх майстрів виробничого навчання транспортного профрілю, ми керуємося тим, що використання завдань виробничого характеру в освіті сприяє інтенсиорікації й підвищенню ефрективності процесу навчання, створює умови для самоосвіти і саморозвитку, у поєднанні з інноваційними технологіями розв'язує проблему доступу до нових джерел навчальної інформації.

В умовах реформування української освіти вагомого значення набуває оновлення ії змісту, пошук та реалізація новітніх принципів навчання. Зміст сучасної технічної освіти передбачає не тільки сукупність знань про природу, технічне обладнання, культуру і способи діяльності населення, але і досвід творчої, інтелектуальної, пошукової діяльності з розв'язання виробничих завдань.

Сучасні вимоги до кваліфікованого фрахівця змушують коригувати освітній процес, робочі та навчальні програми, педагогічні технології. Як зазначає В. Кремень, «передові освітні практики <...> приводять до нової якості знання і, нарешті, до нової, інноваційної людини. Головне - не застигати, не зупинятися в наявних знаннях» [9, с. 7]. Саме тому актуальні перегляд і модиорікація змісту традиційних навчальних дисциплін, перехід від стандартного до спеціалізованого викладу фундаментальних дисциплін у фрахових передвищих та вищих навчальних закладах.

Суспільство вимагає від людини як високої компетентності у професійній галузі, так і розвинутих інтелектуальних умінь, що є основою для подальшого самовдосконалення [7, с. 236]. В умовах закладу фрахової передвищої освіти фрундаменталізацію освітнього процесу варто забезпечити завдяки інтенсифрікації навчання й опанування майстрами виробничого навчання транспортного профрілю узагальнених знань і умінь. Досягнення такої мети можливе через виділення в освітньому процесі компонента, що не зводиться до змісту дисциплінарних знань, а орієнтований на розвиток творчих можливостей студентів.

Під змістом освіти дослідники розуміють систему знань, умінь, навичок, фрормування світогляду, творчу діяльність, моральну поведінку, підготовку до суспільного життя, які зумовлені вимогами суспільства до кадрів відповідної кваліфрікації і профрілю. На досягнення яких повинні бути спрямовані зусилля педагогів і студентів у навчальних закладах вищої та фрахової передвищої освіти, що забезпечують здобуття освіти даного рівня [2; 3; 5; 11].

Найбільш повно визначено зміст освіти в Законі України «Про вищу освіту»: зміст вищої освіти - це зумовлена цілями та потребами суспільства система знань, умінь та навичок, професійних, світоглядних і громадянських якостей, що має бути сорормована у процесі навчання з урахуванням перспектив розвитку суспільства, науки, техніки, технологій, культури та мистецтва [4].

Як зазначає В. Краєвський [8, с. 12], через педагогічну модель соціального замовлення можна подати зміст освіти. Водночас педагогічна модель визначає необхідність педагогічної інтерпретації соціального замовлення, а це, у свою чергу, визначає залежність обсягу і структури змісту від закономірностей навчання майстрів виробничого навчання транспортного профрілю. Погоджуємося з висновком, що навчання - це єдине ціле, у якому взаємозалежні викладання і навчання, змістовний і процесуальний компоненти.

У змісті освіти 3. Курлянд у своїх працях виокремлює предметний і загальнодіяльнісний компоненти [10, с. 101]. До складу предметного компонента змісту навчання відбирають оптимальний мінімум профресійно значущих предметних знань, спеціальних практичних умінь та логічного мислення. Для повноцінного вивчення навчальних предметів та модулів змісту виділяють структурні одиниці предметного компонента, ураховують їхній взаємозв'язок. Особливість цих структурних одиниць полягає в тому, що вони можуть використовуватися на будь-якому предметному матеріалі, який вивчає студент, утворюють основу для розвитку творчого ставлення до навчання.

У підготовці майстрів виробничого навчання транспортного профілю до занять велику увагу приділяють розв'язуванню різних видів завдань, тому що вони сприяють:

- зміні організаційних фрорм навчального процесу, структури освітнього процесу загалом;

- фрормуванню навичок продуктивної діяльності: здобуття знань безпосередньо з реальної дійсності; 
- опанування прийомів дій у нестандартних ситуаціях, евристичних методів вирішення проблем;

- фрормування здатності працювати з інорормаційними джерелами, навичок роботи у групі, умінь планувати діяльність із досягнення результату, виконати програму і представити результати своєї діяльності;

- адекватному застосуванню знань для вирішення проблем, що виникають у повсякденному житті;

- зміні фрорм і методів оцінювання.

Профресійна компетентність майстра виробничого навчання транспортного профрілю виступає як здатність застосування вивчених фрормул, законів, явищ та теоретичних знань у вирішенні поставлених завдань, використання набутих на заняттях знань у життєвих ситуаціях. Досвід переконує, що лише налагоджена система дає результат.

Майстри виробничого навчання транспортного профрілю часто виявляються неготовими до розв'язання практичних, навчальних та виробничих завдань і творчої діяльності, не володіють навичками самостійної навчальної діяльності. Причиною цього є недостатнє використання практичних та виробничих завдань, які за вимогами компетентнісного підходу повинні бути наближені до реальних умов життєдіяльності майбутнього майстра виробничого навчання транспортного профрілю, підштовхувати до використання набутих на заняттях знань у життєвих ситуація.

Детальніше розглянемо виробничі завдання в навчальному процесі, які використовуються в підготовці майбутніх майстрів виробничого навчання транспортного профрілю під час фрормування професійної компетентності. Доцільність використання виробничих завдань визначена навчальною програмою, де зазначено, що завдання є однією 3 найважливіших ділянок роботи в системі навчання. Виробничі завдання різних типів можна ефективно використовувати на всіх етапах засвоєння знань: для розвитку компетентності, творчих здібностей, інтересу і мотивації майстрів виробничого навчання транспортного профрілю до навчання, під час постановки виробничої проблеми, що потребує розв'язання, у процесі фрормування нових знань, досвіду, умінь, майстерності студентів, 3 метою закріплення, повторення, упорядкування та підсумовування засвоєного матеріалу, для контролю якості засвоєння навчального матеріалу. В умовах навчального процесу важливо здійснити відповідний добір виробничих завдань, який би враховував пізнавальний інтерес майстрів виробничого навчання транспортного профілю, рівень їхньої готовності до виробничої діяльності, розвивав би їхні здібності відповідно до освітніх потреб.

Наприклад, транспортер ТК-ББ, яким роздають тваринам корм, рухається зі швидкістю 1,5 м/с.
Відстань до крайньої тварини - 80 м. Визначити час, за який буде роздано корм.

Наведений приклад має виробниче завдання 3 визначення часу, протягом якого передається корм тваринам. Розв'язування таких завдань дає змогу викладачу не лише продемонструвати виробниче застосування знань, а й навчити студентів розуміти сутність природничо-технологічних процесів, виконувати параметричні обчислення, необхідні фрахівцям транспортного профрілю, ознайомити ïx із деякими сільськогосподарськими машинами.

Висновки. Формуванню професійної компетентності майбутнього майстра виробничого навчання транспортного профілю слугують педагогічні умови, що гарантують індивідуальний розвиток та реалізація своїх можливостей як базу їхнього професійного становлення, дозволяють створювати максимальні можливості для самореалізації і розвитку педагогічної майстерності.

Упровадження інноваційних технологій у розвиток фрормування професійної компетентності майбутніх майстрів виробничого навчання транспортного профрілю сприятиме фрормуванню вмінь і навичок інфрормаційної й інфрормативної взаємодії, розширенню об'єму навчального матеріалу для розвитку творчих здібностей, налагодженню невимушеного спілкування й покращенню психологічного клімату у студентських групах. Варто зазначити, що застосування інтерактивних технологій вимагає від студентів творчих підходів, логічного мислення та вміння контролювати виробничий процеси за допомогою доступних засобів, одним із таких засобів ми розглянули виробничі завдання.

Отже, виробничі завдання для майстрів виробничого навчання транспортного профрілю фрормують професійну компетентність, що виявляється незалежно від ситуації. Компетентнісний підхід передбачає методичність, сумлінність у підготовці кожної теми до заняття, у підбиранні методів, способів і прийомів, що застосовуються в навчальній діяльності. Форма подачі навчального матеріалу повинна змінюватися на заняттях від загальної до креативної, творчої, нешаблонної, оригінальної за допомогою виробничих завдань для студента транспортного профрілю.

\section{БІБЛІОГРАФІЧНИЙ СПИСОК:}

1. Буркова Л. Задачний підхід у підготовці фрахівців соціальних професій: типи задач та особливості їх розв'язування. Вісник Київський національного університету імені Тараса Шевченка. Серія «Педагогіка». 2015. Вип. 2. С. 11-16.

2. Гершунский Б. Прогнозирование содержания обучения в техникумах. Москва : Высшая школа, 1980. 144 c.

3. Гончаренко С. Український педагогічний словник. Київ : Либідь, 1997. 476 с.

4. Про вищу освіту : Закон України. URL: https://zakon.rada.gov.ua/laws/show/1556-18\#Text (дата звернення: 25.06.2021). 
5. Коваленко О. Методика профресійного навчання : підручник для студентів вищих навчальних закладів. Харків : НУА, 2005. 359 с.

6. Підготовка майбутніх педагогів професійного навчання на засадах компетентнісного підходу : колективна монограсрія / В. Ковальчук та ін. Глухів : Глухівський НПУ ім. О. Довженка, 2020. 194 с.

7. Комп'ютерно орієнтовані системи навчання : збірник наукових праць. Київ : НПУ ім. М.П. Драгоманова. 2001. Вип. 3. 287 с.

8. Краевский В. Проблемы научного обоснования обучения : методологический анализ. Москва : Педагогика, 1977. 264 с.
9. Кремень В. Транссрормації особистості в освітньому просторі сучасної цивілізації. Педагогіка і психологія. 2008. № 2 (59). С. 5-14.

10. Курлянд 3. Педагогіка вищої школи : навчальний посібник. Київ : Знання, 2007. 495 с.

11. Олешков М. Технологии обучения в высшей школе. Ученые записки. Нижнетагильская государственная социально-педагогическая академия. Педагогика. Психология. Нижний Тагил, 2003. C. 47-54.

12. Петренко С. Аналіз понять «компетенція» та «компетентність». Педагогічні науки: теорія, історія, інноваційні технології. 2013. № 2 (28). С. 288-295. 